\title{
Lule Sami Language
}

National Cancer Institute

\section{Source}

National Cancer Institute. Lule Sami Language. NCI Thesaurus. Code C154120.

A Uralic Sami language spoken in Lule Lappmark, Sweden and in the northern parts of Nordland county in Norway. 